\title{
AKTIVNOSTI MLADIH U DRUŠTVENOJ ZAJEDNICI - MIŠLJENJE STUDENATA (BUDUĆIH UČITELJA I NASTAVNIKA)
}

\author{
Marina Diković \\ Fakultet za odgojne i obrazovne znanosti Sveučilišta Jurja Dobrile u Puli, Republika Hrvatska \\ Tina Drenjančević \\ Fakultet za odgojne i obrazovne znanosti Sveučilišta Jurja Dobrile u Puli, Republika Hrvatska
}

\begin{abstract}
Sažetak
Sudjelovanje mladih u aktivnostima društvene zajednice jedan je od važnih aspekata aktivnoga građanstva. Razvija se Građanskim odgojem i obrazovanjem koji se u hrvatskom odgojno-obrazovnom sustavu provodi od 2014. kao obvezno područje kojemu je cilj, između ostaloga, usvojiti kompetencije za uključivanje u aktivnosti društvene zajednice. Cilj istraživanja u radu bio je ispitati mišljenje studenata (budućih učitelja i nastavnika) o učeničkom dostizanju ishoda učenja s obzirom na znanje, vještine i stavove na temelju Kurikuluma za međupredmetnu temu Građanski odgoj i obrazovanje za osnovne i srednje škole u Republici Hrvatskoj (10/2019). U istraživanju je sudjelovalo 109 studenata Sveučilišta Jurja Dobrile u Puli. Za potrebe ovoga istraživanja studenti su podijeljeni u dvije grupe, oni koji su se samoprocijenili kao aktivni i oni koji se smatraju neaktivnima u društvenoj zajednici. Više razlika postoji u mišljenju studenata o dostizanju ishoda učenja s obzirom na znanje, zatim ishoda učenja s obzirom na vještine, ali ne postoje razlike u mišljenju o dostizanju ishoda učenja s obzirom na stavove. Studenti Fakulteta za odgojne i obrazovne znanosti bolje procjenjuju ishode učenja s obzirom na znanje, vještine i stavove. Potrebno je da djeca i mladi prakticiraju aktivno građanstvo kako bi mogli oblikovati stavove kao važan segment građanske kompetencije.
\end{abstract}

Ključne riječi: građanski odgoj i obrazovanje, ishodi učenja, mišljenje studenata, zajednica

\section{UvoD}

Djecu i mlade trebalo bi što ranije uključiti u aktivnosti društvene zajednice kako bi mogli razvijati građansku kompetenciju koja je toliko važna za aktivno građanstvo. Prva zajednica djetetu pri polasku u školi je razredno odjeljenje. Koncentrični se krugovi šire prema školskoj zajednici. Tako mladi polaskom u srednju školu shvaćaju da je zajednica škole proširena na društvenu zajednicu koja se može promatrati u lokalnom, regionalnom i nacionalnom kontekstu, ali i europskom i međunarodnom kontekstu na koje danas mladi gledaju kao na nešto što im je vrlo blisko. Prema Zeman i Zeman (2010, str. 7) ideja je zajednice „tijekom posljednjih dvaju stoljeća intenzivno zaokupljala društvene znanosti, zauzimajući posebno važno mjesto u sociologiji." Isti autori opisuju povijesni aspekt zajednice i njezinoga nastajanja te izbor definicija zajednice u 20. stoljeću (2010, str. 25). Također, postoji klasifikacija socioloških pristupa zajednici (prema Bell i Newby, 1971, str. 32-53, u Zeman i Zeman, 2010, str. 27) i to: ekološki pristup, zajednica kao organizacija, zajednica kao mikrokozmos, zajednice kao tipovi, zajednice - lokaliteti mreže i zajednice kao metode istraživanja. Tönnies (2002) razlikuje zajednicu (njem. gemeinschaft) i društvo (njem. gesellschaf) i tumači ih kao dinamične "suprotstavljene tipove društvenoga života“. Zajednicu je potrebno (re)definirati i tumačiti u kontekstu modernoga 
društva. Sve se više u nju uključuju osobe različitih kultura te je trebamo analizirati s interdisciplinarnoga stajališta. „U suvremenom društvu na djelu su međusobno suprotstavljane koncepcije multikulturalizma kao suživota različitih etničkih, socijalnih i interesnih zajednica i 'sudara civilizacija' kao procesa globalnoga povezivanja kulturno srodnih nacija u različite velike civilizacijske zajednice" (Spajić-Vrkaš, Kukoč i Bašić, 2001, str. 626). Multikulturalizam se danas tumači kao statički termin i potrebno ga je objasniti u kontekstu dinamike. Tada on prerasta u termin interkulturalizam (prema Spajić-Vrkaš, Kukoč i Bašić, 2001).

Suvremeno doba simbolizira potreba za solidarnošću i pripadanjem pa zajednicu možemo tumačiti u tom kontekstu. lako postoje cyber zajednice ili virtualne zajednice (Zeman i Zeman, 2010, str. 54; Baker i sur., 2013; Holgersson i Karlsson, 2014), kozmopolitske zajednice (komunikacijske zajednice) - svjetske i transnacionalne (Delanty, 2006), ali i druge, za potrebe ovoga rada pojam zajednice tumačimo kao pojam društvene zajednice koje mogu biti lokalne, regionalne, nacionalne i međunarodne (s obzirom na mjesto). Društvene zajednice temelje se na civilnom zalaganju, odnosno sudjelovanju građana u životu zajednice kako bi se unaprijedili uvjeti života (Diller, 2001; Adler i Goggin, 2005; Batarelo i sur., 2010; Hart, 2013; Checkoway, 2011). "Civilno zalaganje obuhvaća pojam i ideju globalnoga građanstva i uzajamne ovisnosti“ (Ledić i Ćulum, 2010. str. 72). Ledić i Ćulum (2010, str. 71) analiziraju povezanost između „civilne misije sveučilišta, visokoškolske nastave (kao jedne od temeljnih akademskih djelatnosti) i obrazovanja društveno odgovornih i aktivnih građana“, a oblik u kojem se očituje aktivni angažman mladih (studenata) nazivaju učenje zalaganjem u zajednici kao jednan od modela iskustvenoga učenja.

U demokratskom europskom društvu posljednjih se godina pojavljuje definicija suvremenoga demokratskog građanina kojom se objašnjava da je građanin informirani i aktivan pojedinac koji je sposoban sudjelovati u životu svoje i globalne zajednice s preuzimanjem odgovornosti (Spajić-Vrkaš, Kukoč i Bašić, 2001). Govoreći o kontekstu građanstva, Delanty (2000) razvija pojam kulturnoga građanstva (engl. cultural citizenship) u terminima procesa učenja na individualnoj i zajedničkoj razini (za njega je građanstvo proces učenja) jer, kako navodi, neki procesi ne zahtijevaju samo kognitivne kompetencije, već imaju razvijajući i transformirajući utjecaj na subjekta koji uči. Prednost teoretiziranju kulturnoga građanstva kao procesa učenja jest da kulturno građanstvo mijenja usmjerenost (interes) s pukoga političkoga članstva na zajedničko iskustvo, kognitivne procese, oblike kulturnoga prenošenja i rasprave okoline jer, prema spomenutom autoru, građanstvo ima veliki utjecaj na kulturne procese u društvu. On, dakle, građanstvo vidi kao konstruktivni (koristan) proces. Sudjelovanje kao važan pojam u objašnjavanju pojma zajednice ne odnosi se samo na politički aspekt već i na kulturalne i političke aktivnosti okoline na lokalnoj, regionalnoj i nacionalnoj, europskoj i međunarodnoj razini (Hoskins, 2006). Hoskins (2006. str. 5) navodi da je „aktivno građanstvo aktivno sudjelovanje u građanskom društvu, zajednici i/ili političkom životu, karakterizirano uzajamnim poštovanjem, a ne zlostavljanjem, u skladu s ljudskim pravima i demokracijom." Isti autor donosi osnovne elemente aktivnoga građanstva koje čini lista od četiri dimenzije: 1. političko sudjelovanje glasovanje na svim razinama; utjecaj na odlučivanje (engl. lobbying); postizanje vlastitih interesa građana: sudjelovanje unutar zastupničkoga sustava, aktivnosti unutar participatorne demokracije (engl. participatory democracy), aktivnosti orijentirane vrijednošću; 2 . društveno sudjelovanje - postati članom volonterske organizacije ili odbora neke organizacije te sudjelovanje u nekim drugim aktivnostima organizacije; 3 . kulturno sudjelovanje - borba protiv isključivanja i diskriminacije (društvena i kulturna dimenzija - odnose se na aktivnosti koje promiču zadovoljstvo (blagostanje) i one koje stvaraju „zajedničko vlasništvo“ zajednice); 4. ekonomsko sudjelovanje - sudjelovanje u procesu proizvodnje; postati članom radničkoga vijeća, poduzeti akcije protiv nejednakih globalnih raspodjela u svijetu - sudjelovanje na tržištu rada i u „razmjeni roba i usluga." Mesić (2006) analizira pitanje građanstva u kontekstu multikulturalizma i pokušava ponovno definirati različitost. Analizira utjecaj globalizacije na odnose moći i mjesta, njezino detaljnije bavljenje i uočavanje prepreka ideologije relativno autonomne nacionalne 
Marina Diković, Tina Drenjančević AKTIVNOSTI MLADIH U DRUŠTVENOJ ZAJEDNICI - MIŠLENJE...

kulture te pokretljivosti ljudi preko nacionalnih granica. Prema tom autoru sve to rezultira heterogenim, kulturno raznolikijim stanovništvom.

Mladi percipiraju neke aspekte društva u kojem žive nepravednim u visokom stupnju (prema istraživanju Ljubotina, 2004). Ako još uzmemo u obzir činjenicu da „osjećaj pojedinca ne može utjecati na društvene procese i vodi ka pasivnosti i marginalizaciji“ (Ljubotina, 2004, str. 171), moramo kod djece i mladih od početka školovanja promicati društvenu uključenost i zalaganje za dobrobit članova zajednice, ali i same zajednice kao takve. U protivnom nećemo moći uočavati napredak u aktivnostima mladih u društvenoj zajednici. Prema podacima nekih istraživanja iz područja volontiranja (Kotlar i sur., 2016) potrebno je mlade (studente ${ }^{1}$ ) sve više informirati o volontiranju i volonterstvu, a posebno one studente koji se nisu okušali u volonterskim aktivnostima. Studenti i nastavnici, prema nevedenom istraživanju, uočavaju osobnu i društvenu vrijednost volontiranja i to za akademsku, ali i za lokalnu, regionalnu i širu zajednicu.

\section{Aktivno građanstvo u hrvatskom odgoju i obrazovanju}

Škole kao zajednice trebaju se baviti odgojem više nego ikada prije. Autorica BuljubašićKuzmanović (2012) analizira školu kao zajednicu odrastanja i uspješnosti različitim školskim aktivnostima. $U$ tom smislu škole trebaju promicati uključenost učenika u zajednicu kako bi se razvili dobri međuljudski odnosi. Hrvatski školski sustav u koji je ugrađen suvremeni europski model odgoja i obrazovanja prilagođen potrebama hrvatskoga društva može biti prihvatljiv jedino ako sadrži učinkovite i pozitivne strane kulturalnoga i gospodarskoga napretka, ali i cjelokupnih uvjeta življenja. Učeničke potrebe uvjetovane su sve složenijim procesima rada, a nametnute su u smislu stvaranja novih paradigmi učenja i novih oblika nastave (Skok, 2004). Budući da ti zahtjevi nastaju iz potrebe za kvalitetnijim načinom rada, počinjemo tragati za još učinkovitijom nastavom, kako u okviru škole, tako i izvan nje. U skladu s tim, u odgoju i obrazovanju prihvaćaju se nova načela učenja i poučavanja s ciljem stjecanja znanja i vještina koja su otvorena inovacijama i nadograđivanju sukladno ubrzanim promjenama u društvu, kulturi, gospodarstvu, znanosti i tehnologiji. Upravo je odgoj i obrazovanje ono što potiče svjesnost učenika o ljudskim pravima i odgovornostima te utječe na razvijanje sudjelovanja u društvenoj zajednici i na stvaranje građanske kompetencije (Diković, 2013a).

U hrvatske škole uveden je Građanski odgoj i obrazovanje kao posebno odgojno-obrazovno područje, povezano s odgojem i obrazovanjem za ljudska prava, koje se temelji na odgoju i obrazovanju koji učenike priprema za aktivno i odgovorno građanstvo tako što ih uči potrebnim znanjima, vještinama i stavovima kojima mogu pridonijeti razvoju i dobrobiti društva u kojem žive. To područje u osnovi ima pripremanje i stvaranje odgovornih i aktivnih građana koji poznaju i promiču svoja prava. Društveno djelovanje djece i mladih u suvremenome društvu sve više postaje prioritet demokratskih zajednica, a neki autori (Bašić, 2007) naglašavaju da je odgoj i obrazovanje za ljudska prava dobar model i pokretač inicijativnosti za sudjelovanje mladih u različitim institucijama društvenoga života.

Građanski odgoj i obrazovanje u hrvatskim školama godinama se usustavljivao različitim temama unutar obaveznih predmeta. Odgoj i obrazovanje za ljudska prava i demokratsko građanstvo provodi se još od 1999., a sadržaji tog područja 2014. godine postaju obavezni međupredmetnom temom Građanskoga odgoja i obrazovanja. ${ }^{2}$ Jedan je od zadataka škole dati učenicima smjernice za aktivno sudjelovanje u aktivnostima društvenoga života, a to je moguće samo uz poticajno školsko ozračje (Domović, 2004) u kojem će učenici razvijati građanske

\footnotetext{
Muški rod u radu s upotrebljavakao generički oblik.

Građanski odgoj i obrazovanje od 2014. provodi se prema Programu međupredmetnih i interdisciplinarnihSadržaja građanskog odgoja i obrazovanja za osnovne i srednje škole. Dostupno na: https://mzo.hr/sites/default/files/ migrated/program_go_os_ss.pdf (19.4.2019.)
} 
vještine. Dakle, o ozračju u školama, uz mnoge druge aspekte, ovisit će uključenost učenika u aktivnosti zajednice u sklopu Građanskoga odgoja i obrazovanja.

Prema Nacionalnom okvirnom kurikulumu za predškolski odgoj i obrazovanje te opće obavezno i srednjoškolsko obrazovanje (MZO, 2011) građanski odgoj i obrazovanje međupredmetna je tema čija je svrha osposobiti učenike za učinkovito i aktivno obavljanje svoje građanske dužnosti. Značajni elementi u poučavanju su znanja, vještine i stavovi koji će razviti demokratsku svijest učenika i poticati ih na aktivno sudjelovanje u demokratskim odnosima u zajednici. U prijedlogu Nacionalnoga kurikuluma međupredmetne teme Građanskoga odgoja i obrazovanja $^{3}$ iz 2016. navode se odgojno-obrazovni ciklusi kao odgojno-obrazovna razdoblja za učenike ovisno o njihovoj dobi odnosno razredu. Odgojno-obrazovni ciklusi razvojna su razdoblja učenika i čine cjelinu te obuhvaćaju određene godine školovanja u određenoj odgojnoobrazovnoj razini učenika. Ciklusi imaju zajedničke odgojno-obrazovne ciljeve, tj. predviđena očekivanja koja bi učenik trebao postići u predviđenom razvojnom ciklusu. Odgojno-obrazovni ciklusi temeljeni su na razvojnim fazama učenika koje obuhvaćaju obavezno osnovno i srednjoškolsko obrazovanje za stjecanje kompetencija. Ciklusi su: prvi ciklus (čine ga prvi i drugi razred osnovne škole), zatim drugi ciklus (čine ga treći, četvrti i peti razred osnovne škole), treći ciklus (šesti, sedmi i osmi razred osnovne škole) i četvrti ciklus (srednja škola).

Određivanje ciklusa po razredima omogućuje cjelovitije zahvaćanje razvoja učenika uzimajući u obzir razlike u njihovim sposobnostima. Ukupno je pet odgojno-obrazovnih ciklusa koji su podijeljeni po razredima. Općenito, nacionalnim kurikulumima međupredmetnih tema (ima ih sedam) određuje se svrha, ciljevi, struktura, odgojno-obrazovna očekivanja, učenje i poučavanje te vrednovanje određene međupredmetne teme. Odgojno-obrazovni ciljevi jasni su i nedvosmisleni iskazi o očekivanjima od učenika u jednoj od cjelina međupredmetnih tema. $U$ organizaciji kurikuluma postoje tri domene, a njihovim prožimanjem ostvaruju se odgojnoobrazovni ciljevi. Domene su: ljudska prava, demokracija i civilno društvo. Prema navedenom dokumentu Građanski odgoj i obrazovanje međupredmetna je tema sa svrhom osposobljavanja učenika za aktivno obavljanje građanske dužnosti te obuhvaća znanja o pravima, dužnostima i odgovornostima ljudi, a ponajviše se usmjerava na kritičko mišljenje i komunikacijske vještine. Temeljne vrijednosti koje promiče Građanski odgoj i obrazovanje su odgovornost, uvažavanje različitosti i solidarnost, a velika važnost pridaje se upravo razvoju odgovornoga odnosa prema javnom i zajedničkom dobru. Za razvoj građanskih kompetencija nije dovoljno samo poznavanje ljudskih prava i političkih koncepata, već je važno omogućiti prakticiranje tih načela u školama i unutar društvene zajednice.

Posebnosti Građanskoga odgoja i obrazovanja su metode suradničkoga i iskustvenoga učenja te učenje izvan škole. Budući da sam uspjeh poučavanja ovisi o tome koliko će učenici pronaći vlastiti interes, takvim pristupom učenja učenici će razvijati vještine koje će im biti potrebne za suradnju u svim aspektima života. Prema Tatković, Diković i Štifanić (2015, str. 64) „Središnji pojam odgoja i obrazovanja za ljudska prava, odnosno svih srodnih pristupa je aktivan građanin i osnažen građanin, odgovoran za svoje akcije i odnose s drugim građanima“. Jedna od temeljnih svrha učenja o građanstvu upravo je jačanje građanskoga društva kako bi svi građani u demokratskom okruženju mogli učiti sudjelovanjem u zajednici.

Građanski odgoj i obrazovanje danas je obavezno područje u osnovnim i srednjim školama, a provodi se međupredmetno što znači da se u sklopu obaveznih predmeta, ali i u sklopu sata razrednika realiziraju sadržaji Građanskoga odgoja i obrazovanja. Da bi se kod učenika oblikovala spremnost za odgovorno i aktivno sudjelovanje u zajednici, u školi će steći znanje o odgovornostima, mogućnostima i načinima djelovanja zajednice, o mehanizmima zaštite ljudskih prava te razvijati vještine za uočavanje problema zajednice i za njihovo rješavanje. Kako bi se sve to ostvarilo, nastavni plan i program za Građanski odgoj i obrazovanje određuje očekivana postignuća učenika te predlaže načine na koje bi se u školi ta postignuća ostvarila.

3 Dostupno na: http://www.kurikulum.hr/wp-content/uploads/2016/03/Građanski-odgoj.pdf (19.4.2019.) 
Marina Diković, Tina Drenjančević AKTIVNOSTI MLADIH U DRUŠTVENOJ ZAJEDNICI - MIŠLENJE.

Građanski odgoj i obrazovanje predstavlja okvir za razvoj građanske kompetencije u školi. Kako bi škola postala upravo takvo mjesto za poučavanje i življenje demokracije, ključna je suradnja svih djelatnika u odgoju i obrazovanju. Pri tome se pretpostavlja da je moguće Građanski odgoj i obrazovanje izravno povezati sa svim nastavnim predmetima. Prema Diković (2013b, str. 328) građanska kompetencija (s interpersonalnim, interkulturalnim i društvenim kompetencijama), kao jedno od osam područja kompetencija, „zauzima važno mjesto u obrazovanju prema Europskom referentnom okviru za sve članice Europske unije iz 2006. godine.“ Također, Diković (2013b) objašnjava da se građanska kompetencija određuje kao skup kompetencija koje će omogućiti pojedincu sudjelovanje u građanskom društvu, npr. zastupanje svojih stavova argumentima, kritičkim prihvaćanjem informacija, spremnosti sudjelovanja u različitim građanskim aktivnostima te prihvaćanjem samog koncepta ljudskih prava.

Učenici trebaju postati odgovorni članovi razredne i školske, lokalne, regionalne i nacionalne (državne) te globalne zajednice. Upravo Građanski odgoj učenicima omogućava jednostavnije snalaženje u društvu, pronalaženje odgovora na pitanja koja si postavljaju i rješenja za moguće društvene izazove oko njih. Učenici se kroz Građanski odgoj i obrazovanje osposobljavaju za uspješno sudjelovanje u životu zajednice stjecanjem građanske kompetencije koja uključuje znanje, vještine i stavove. Građanski odgoj i obrazovanje omogućuje znanja o dužnostima i pravima pojedinca, znanja o demokratskoj zajednici i političkim oblicima. Kritičko mišljenje i komunikacijske vještine sa socijalnim vještinama vještine su na koje je Građanski odgoj i obrazovanje najviše usmjeren. Za razvoj građanske kompetencije potrebno je omogućiti prakticiranje demokratskih načela u školama i društvenim zajednicama jer nije dovoljno samo da učenici poznaju političke koncepte i svoja prava, već i da ih prakticiraju.

Prema najrecentnijem dokumentu iz područja Građanskoga odgoja i obrazovanja, Odluka o donošenju kurikuluma za međupredmetnu temu Građanski odgoj i obrazovanje za osnovne i srednje škole u Republici Hrvatskoj (NN 10/2019), treća se domena razvija u domenu Društvena zajednica. Ona svojim sadržajem učenika usmjerava na aktivno djelovanje u zajednici. Aktivnim djelovanjem odnosno participacijom učenici stječu znanja i razvijaju vještine i stavove o važnosti osobnih i zajedničkih stavova u zajednici. Učenik sudjelovanjem u zajednici reagira na društvenu isključenost i priprema se za uspješno djelovanje i uočavanje problema, istražuje i pronalazi rješenja uključivanjem u aktivnosti zajednice. Pojedinac će zalaganjem u društvenoj zajednici te sudjelovanjem u radu udruga i nevladinih organizacija koje promiču zajednički interes i zaštitu ljudskih prava kasnije prerasti u građansku inicijativu i zalaganje za promicanje vlastitih ideja za dobrobit društva. Solidarno djelovanje i volontiranje postaje dijelom obrasca ponašanja za opće dobro kod učenika.

U sklopu domene Društvena zajednica (prema najnovijem Kurikulumu iz 2019.) naglasak je na razvoju znanja, vještina i stavova koji će pripremiti i osposobiti učenike za zajednički rad i uključenost u zajednicu, užu i širu. Također, razvijaju se vještine koje su važne za razvoj kulture u školi kao što su održavanje vrijednosti, vjerovanja, normi, običaja i rituala a te su vještine komunikacijske i socijalne. Dio njihova obrasca ponašanja postaju upravo volontiranje i solidarno djelovanje učenika. Učenicima se pruža mogućnost društvenoga sudjelovanja, inicijative i pregovaranja sudjelovanjem u akcijama udruživanja i djelovanja građana u okviru civilnoga društva. U civilnom društvu učenici mogu uočiti posljedice odnosa prema javnoj imovini, a promicanjem kvalitete života mogu unaprijediti zajedništvo i društvenu solidarnost, životne uvjete i povjerenje, od razredne do lokalne, nacionalne i globalne zajednice. Prvi i drugi odgojno-obrazovni ciklusi obuhvaćaju ishode učenja za razrednu nastavu unutar međupredmetne teme Građanski odgoj i obrazovanje. Istraživanje u ovome radu temelji se na domeni Društvena zajednica, na prvom i drugom ciklusu. Učenik bi na kraju 1. i 2. ciklusa trebao postići sljedeća odgojno-obrazovna očekivanja: sudjeluje u zajedničkom radu u razredu, promiče solidarnost u razredu, promiče kvalitetu života u razredu, promiče razvoj razredne zajednice i demokratizaciju škole (za prvi ciklus) te sudjeluje u unaprjeđenju života i rada škole, promiče solidarnost u školi, promiče kvalitetu života u školi i demokratizaciju škole i promiče razvoj školske kulture 
i demokratizaciju škole (drugi ciklus). Sva su ta očekivanja u Kurikulumu (10/2019) razrađena na ishode učenja s obzirom na znanje, vještine i stavove.

\section{Metoda $^{4}$}

\section{Cilj istraživanja}

Cilj istraživanja u radu bio je ispitati mišljenje studenata o dostizanju ishoda učenja (znanja, vještina i stavova) učenika primarnoga obrazovanja na primjeru ishoda učenja iz Građanskoga odgoja i obrazovanja.

\section{Hipoteze}

H1 Studenti koji se smatraju aktivnima bolje procjenjuju dostizanje ishoda učenja s obzirom na znanje, vještine i stavove.

H2 Nema razlika u mišljenjima studenata s obzirom na studij. Bez obzira na to studiraju li studenti na Filozofskom ili na Učiteljskom fakultetu, dobro procjenjuju dostizanje ishoda učenja s obzirom na znanje, vještine i stavove.

\section{Instrument i postupak}

Za potrebe ovoga istraživanja kreirane su Likertove skale od 5 stupnjeva (od $1=$,,izrazito malo“ do 5 = „vrlo mnogo“) u kojima su ponuđeni ishodi učenja (znanje, vještine i stavovi) dokumenta Kurikulum za međupredmetnu temu Građanski odgoj i obrazovanje za osnovne $i$ srednje škole u Republici Hrvatskoj $(10 / 2019)^{5}$ koji se razvio na temelju Kurikuluma za međupredmetnu temu Građanski odgoj i obrazovanje za osnovne i srednje škole u Republici Hrvatskoj iz 2016. nastao u sklopu Cjelovite kurikularne reforme. Svi ishodi učenja pripadaju domeni Društvena zajedica kao jednoj od tri domene u tom dokumentu. Prva skala sadrži 10 ishoda učenja, druga 16, a treća 12.

\section{Uzorak}

$\mathrm{U}$ istraživanju je sudjelovalo 109 studenata. Od tog broja 24 studenata i 85 studentica. Prosječna dob studenata iznosi 21 godinu s rasponom od 18 do 43 godine. Od ukupnoga broja ( $N=109)$ najviše je studenata između 20 i 22 godine. Prosjek studijske godine obuhvaćene ovim istraživanjem pokazuje da je najviše studenata s treće godine studija ( $N=35,32,1 \%)$. Nadalje, njih 30 je s četvrte godine studija, a $22 \mathrm{~s}$ druge godine. Ostatak pripada prvoj ( $\mathrm{N}=18,16,5 \%) \mathrm{i}$ petoj godini ( $\mathrm{N}=4,3,7 \%$ ). Istraživanje obuhvaća raspon od 5 studijskih godina različitih smjerova, dio je studenata s Fakulteta za odgojne i obrazovne znanosti (Učiteljski studij) ( $N=55$, $51 \%$ ), a dio s Filozofskoga fakulteta ( $N=54,49 \%$ ) Sveučilišta Jurja Dobrile u Puli.

\footnotetext{
4 Istraživanje iz ovoga rada dio je opsežnijega istraživanja odnosno dio diplomskoga rada Tine Drenjančević (mentorica Marina Diković) naslova Suradnja odgojno-obrazovnih ustanova s lokalnom zajednicom na Fakultetu za odgojne i obrazovne znanosti Sveučilišta Jurja Dobrile u Puli.

5 Dostupno na: https://narodne-novine.nn.hr/clanci/sluzbeni/2019_01_10_217.html (15.4.2019.)
} 


\section{REZULTATI I RASPRAVA}

Uključenost mladih u aktivnosti društvene zajednice važno je iz više razloga. Prvi je razlog taj da mladi na taj način usvajaju načine doprinosa zajednici. Nadalje, mladi će u svemu dobiti mnogo jer će u sklopu raznovrsnih aktivnosti moći pokazati koliko vrijedi njihov doprinos, ali i koliko će oni sami osobno rasti u aktivnom procesu stjecanja kompetencija za građansko djelovanje. Studenti, budući učitelji/nastavnici trebali bi biti uključeni u aktivnosti zajednice kako bi postali uzor djeci - učenicima s kojima će raditi kada završe studij. $U$ tome i jest velika važnost samoprocjene o njihovoj uključenosti u život i rad zajednice.

$\mathrm{U}$ istraživanju se od ukupnoga broja ispitanika $(\mathrm{N}=109)$ njih čak $48(44 \%)$ izjasnilo da se vrlo malo uključuju u rad zajednice, a samo 4 studenta $(3,7 \%)$ da vrlo mnogo sudjeluju u aktivnostima svoje zajednice. Ukupno 27 studenata $(24,8 \%)$ odgovorilo je da su osrednje uključeni u zajednicu. lako su se očekivale drugačije procjene i veća uključenost studenata u aktivnost zajednice, možemo utvrditi da razlozi takvih rezultata mogu biti uvjetovani različitim čimbenicima, a neke od mogućnosti za poboljšanje su uključivanje učenika u rad zajednice već od djetinjstva. Od početka školovanja učenika potrebno je raditi na usvajanju znanja učenika o zajednici u kojoj žive te usvajanju vrijednosti i oblikovanju stavova o tome. To se može postići, primjerice, različitim temama na satu razredne zajednice ili projektima u sklopu izvanučioničke nastave, provođenjem Građanskoga odgoja i obrazovanja u svim njegovim oblicima. Mlade treba poticati za uključivanje u rad zajednice te time promovirati 'pozitivan razvoj mladih' (Bašić, 2007). Rezultati nekih istraživanja (Ljubotina, 2004) ukazuju na to da značajan broj mladih uočava socijalnu nepravdu u odnosima u društvenoj zajednici. Možda je i to razlog (ne)uključenosti mladih u djelovanje zajednice u kojoj žive i rade.

$\mathrm{U}$ daljnjoj analizi podataka u ovome radu studente smo podijelili u dvije grupe, one koji se smatraju aktivnima i one koji procijenjuju da nisu aktivni. Na taj su način i obrađeni podaci.

\section{Razlike između studenata koji su se procijenili aktivnima i neaktivnima}

U pitanju o dostizanju ishoda učenja s obzirom na znanje postoji više razlika u odgovorima studenata. Ishod učenja Objašnjava osobnu odgovornost pojedinca prema razrednoj zajednici. studenti koji nisu aktivni procjenjuju kao manje dostižan $(M=3.34 ; S D=1.03) \mathrm{u}$ odnosu na aktivne studente $(M=3.87 ; S D=0.83),(t=2.74 ; p=0.007)$. Ishod učenja Objašnjava primjereno postupanje prema privatnoj imovini $i$ javnom dobru. studenti koji nisu aktivni ponovno procjenjuju kao ishod koji je manje dostižan $(M=3.63 ; S D=0.94)$ u odnosu na aktivne studente $(M=4.08 ; S D=0.77)$, $(t=2.55 ; p=0.012)$. Ishod učenja Poznaje svoju ulogu u razvoju školske kulture i demokratizaciji škole. studenti koji nisu aktivni procjenjuju kao manje dostižan $(M=3.41 ; S D=1.11)$ u odnosu na aktivne studente $(M=3.90 ; S D=0.85),(t=2.36 ; p=0.020)$. Mladi koji nisu aktivni ne mogu procijeniti ishode učenja s obzirom na znanje kao lako dostižne. Da bi djeca i mladi uopće bili aktivni, potrebno je da imaju usvojene činjenice, da objašnjavaju ključne pojmove koje se odnose na društvenu zajednicu te da mogu opisati svoje obaveze na temelju normativne osnove. Prema Batarelo i suradnicima (2010) poznavanje ljudskih prava i priprema mladih za informirane, aktivne i odgovorne građane jedan je od najvažnijih ciljeva svake društvene zajednice. Procjenjuju li to nastavnici u odnosu na učenike i shvaćaju li da je važno poznavanje ključnih pojmova iz tog područja, utoliko su rezultati vrjedniji (Batarelo i sur., 2010).

U pitanju da procijene u kojoj će mjeri njihovi budući učenici dostići navedene ishode učenja s obzirom na vještine, studenti koji nisu aktivni manje procjenjuju $(M=3.41 ; S D=1.00)$ dostizanje ishoda Svojim ponašanjem doprinosi razvoju školske kulture i demokratizaciji škole. od studenata koji su aktivni $(M=3.90 ; S D=0.88),(t=2.52 ; p=0.013)$. Domović (2004) definira školsku kulturu kao relativno trajnu kvalitetu školske sredine koja utječe na ponašanje njezinih članova. S obzirom na to da školska kultura utječe na način življenja i da se ogleda u aktivnom 
sudjelovanju učenika koji će razvijati vještine građanskog djelovanja, važnost prakticiranja takvih aktivnosti na početku obrazovanja tim su veće. U školi bi trebao prevladavati demokratski stil vođenja. Vođenje je u takvim školama temeljeno na ljudskim pravima, ali i sudjelovanju učenika u donošenju važnijih odluka (Bäckman, Trafford, 2007). Demokratizacija škole temeljna je pretpostavka usklađenosti demokratskih vrijednosti kojima se učenici poučavaju u izravnom iskustvu (Vrgoč, 1997). Stoga, dostići vještinu građanskoga djelovanja unutar školske kulture i time promicati demokratizaciju škole u razdoblju primarnoga obrazovanja, predstavlja izazov kako za učenika tako i za učitelja, ali i cjelokupni školski sustav.

Nisu pronađene razlike u odgovorima studenata s obzirom na stavove. Prema našem istraživanju stavovi studenata o dostizanju ishoda učenja s obzirom na stavove visoki su (od $M$ $=3,51 ; S D=0,92$ do $M=4,25 ; S D=0,89$ ), a bez obzira na to što nisu pronađene razlike između aktivnih i neaktivnih studenata, možemo zaključiti da se u velikoj mjeri mogu dostizati. U prilog tome govori činjenica da mladi, kako sazrijevaju, uočavaju različite oblike društvenih utjecaja (Flanagan, Tucker, 1999) i procjenjuju dostizanje oblikovanja stavova kao nešto što je u društvenoj zajednici zaista potrebno.

Tablica 1. Razlike u odgovorima studenata s obzirom na aktivnost u zajednici

\begin{tabular}{|c|c|c|c|c|}
\hline \multirow[b]{2}{*}{ Ishodi učenja } & \multicolumn{2}{|c|}{ Aktivnost studenata u zajednici } & \multirow[b]{2}{*}{$\begin{array}{l}\mathrm{F} \\
\mathrm{df}\end{array}$} & \multirow[b]{2}{*}{ Sheffè } \\
\hline & $\begin{array}{l}\text { Aktivni (A) } \\
\qquad \begin{array}{c}M \\
\text { SD } \\
n=39\end{array}\end{array}$ & $\begin{array}{c}\text { Neaktivni (N) } \\
\text { M } \\
\text { SD } \\
n=70\end{array}$ & & \\
\hline $\begin{array}{l}\text { Objašnjava osobnu odgovornost } \\
\text { pojedinca prema razrednoj zajednici. } \\
\text { (znanje) }\end{array}$ & $\begin{array}{l}3.87 \\
0.83\end{array}$ & $\begin{array}{l}3.34 \\
1.03\end{array}$ & $\begin{array}{l}3.537^{* *} \\
107\end{array}$ & $A-N$ \\
\hline $\begin{array}{l}\text { Objašnjava primjereno postupanje } \\
\text { prema privatnoj imovini i javnom } \\
\text { dobru. (znanje) }\end{array}$ & $\begin{array}{l}4.08 \\
0.77\end{array}$ & $\begin{array}{l}3.63 \\
0.94\end{array}$ & $\begin{array}{l}3.074^{*} \\
107\end{array}$ & $A-N$ \\
\hline $\begin{array}{l}\text { Poznaje svoju ulogu u razvoju školske } \\
\text { kulture i demokratizaciji škole. (znanje) }\end{array}$ & $\begin{array}{l}3.90 \\
0.85\end{array}$ & $\begin{array}{l}3.41 \\
1.11\end{array}$ & $\begin{array}{l}3.313^{*} \\
107\end{array}$ & $A-N$ \\
\hline $\begin{array}{l}\text { Svojim ponašanjem doprinosi razvoju } \\
\text { školske kulture i demokratizaciji škole. } \\
\text { (vještina) }\end{array}$ & $\begin{array}{l}3.90 \\
0.88\end{array}$ & $\begin{array}{l}3.41 \\
1.00\end{array}$ & $\begin{array}{l}0.568^{*} \\
107\end{array}$ & $A-N$ \\
\hline
\end{tabular}

${ }^{*} p<.01 ;{ }^{* *} p<.001$

Hipoteza (H1) koju smo trebali provjeriti da studenti koji se smatraju aktivnima bolje procjenjuju dostizanje ishoda učenja s obzirom na znanje, vještine i stavove djelomično je potvrđena. Naime, utvrđene su razlike s obzirom na znanje i vještine u nekim tvrdnjama, ali uopće nisu u ishodima učenja s obzirom na stavove. Procjene $u$ ishodima učenja s obzirom na stavove općenito su visoke što znači da studenti imaju razvijeno visoko mišljenje o dostizanju ishoda učenja iz tog područja.

\section{Razlike u odgovorima studenata s obzirom na studij}

Podaci su za potrebe daljnje interpretacije podijeljeni u dvije grupe. Prvu grupu čine studenti koji studiraju na Učiteljskom studiju, a drugu studenti koji studiraju na studijima Filozofskoga fakulteta. 
Studenti Učiteljskoga studija bolje procjenjuju $(M=4.44 ; S D=0.54)$ dostizanje ishoda učenja s obzirom na znanje Opisuje važnost međusobnog pomaganja. u odnosu na studente Filozofskoga fakulteta $(M=4.15 ; S D=0.86),(t=2.11 ; p=0.037)$. Studenti Učiteljskoga studija bolje procjenjuju $(M=4.00 ; S D=0.82)$ dostizanje ishoda učenja Objašnjava primjereno postupanje prema privatnoj imovini i javom dobru. u odnosu na studente Filozofskoga fakulteta $(M=3.57 ; S D=0.94),(t=2.52 ; p=0.013)$. Možemo tumačiti da studenti Učiteljskoga studija prakticiraju tijekom školske prakse (koju imaju češće u odnosu na studente Filozofskoga fakulteta) i svoga inicijalnog obrazovanja aktivnosti s učenicima u kojima usvajaju osnovne zakonitosti pomaganja i pravilnoga postupanja prema privatnoj imovini. Djeca u svojoj školskoj praksi znanja usvojena o tim pojmovima razumiju i prihvaćaju ih kao činjenice za razliku od tinejdžera koji svoje obrasce ponašanja kasnije mijenjaju u odnosu na usvojeno u školi jer su pod utjecajem funkcionalnih odgojnih sredina, npr. interneta (Miliša, Tolić, Vertovšek, 2009; Mehmedović, 2018), ali i pod utjecajem sveukupne krize odgoja (Zloković, 2010).

Procjene studenata Učiteljskoga fakulteta o dostizanju ishoda učenja s obzirom na vještine Uključuje se u zajedničke aktivnosti razrednog odjela i izvršava svoj dio zadatka. bolje su $(M=4.18 ; S D=0.82)$ za razliku od studenata Filozofskoga fakulteta $(M=3.74 ; S D=0.90),(t=$ 2.69; $p=0.008$ ). Pretpostavka da su aktivnosti u prvim godinama obrazovanja učenika drugačije i organiziranije ukazuje na činjenicu da se učenike više grupira kako bi koristili vršnjačko učenje i da primjena takvoga oblika rada u razrednom odjeljenju doprinosi povoljnijoj procjeni učenika o osobnim vrijednostima i mogućnostima što rezultira boljim testovima znanja (Stanojević, 2009). Također, u vođenju razreda i u poučavanju jedna je učiteljica ili jedan učitelj dok se u višim razredima osnovne škole ili u srednjoj školi poučavanje odvija uz brojne druge učitelje/nastavnike te se s učenicima u manjoj mjeri potiču različite zajedničke aktivnosti u kojima oni imaju priliku realizirati svoj dio zadatka i sudjelovati.

Studenti Učiteljskoga fakulteta slabije procjenjuju dva ishoda učenja s obzirom na vještine u odnosu na kolege s Filozofskoga fakulteta. Dostizanje ishoda učenja Istražuje i koristi se s više izvora informiranja. studenti Učiteljskoga studija slabije procjenjuju $(M=3.36 ; S D=0.93)$ u odnosu na studente Filozofskoga fakulteta $(M=3.87 ; S D=0.88),(t=2.90 ; p=0.005)$. Dostizanje ishoda učenja Prepoznaje pojavne oblike korupcije. studenti Učiteljskoga studija slabije procjenjuju $(M=3.18 ; S D=0.86)$ u odnosu na studente Filozofskoga fakulteta $(M=3.61 ; S D=$ 1.05), ( $t=2.33 ; p=0.022)$. Razlog tomu može biti u činjenici da uporaba raznovrsnih izvora informiranja za učenike na početku školovanja još uvijek predstavlja opterećenje s obzirom na njihove sposobnosti i mogućnosti u toj dobi te da se učenici tek od 5. razreda osnovne škole više koriste medijima (Ilišin, 2003) te na taj način vjerojatno i prate informacije iz različitih izvora. Korupciju također u većoj mjeri mogu razumjeti i analizirati tek stariji učenici. Rezultati istraživanja autora Ćurko i Kragić (2012) pokazuju da učenici 3. i 4. razreda osnovne škole pogrešno tumače pojam korupcije, ali mogu razumjeti i tako apstraktne pojmove ako im se na odgovarajući način približe i ako se koriste prilagođene metode u poučavanju.

Dostizanje ishoda učenja s obzirom na stavove Smatra važnim osobni doprinos unaprjeđenju života i rada škole. bolje procjenjuju studenti Učiteljskoga fakulteta $(M=4.05 ; S D=0.80)$ u odnosu na kolege s Filozofskoga fakulteta $(M=3.66 ; S D=0.94),(t=2.35 ; p=0.021)$. Razlog takvim rezultatima jest u činjenici da studenti Učiteljskoga fakulteta imaju više školske prakse te time poznaju sposobnosti djece i više vjeruju u učeničko oblikovanje stavova. Slika unaprjeđenja života i rada škole iz perspektive studenata - budućih učitelja u primarnom obrazovanju bolja je zbog češćega prakticiranja vještina sudjelovanja u aktivnostima u školama koje na početku obrazovanja promiču mogućnosti oblikovanja mišljenja da smo mi sami važni za doprinos boljitku školske zajednice i da jedino na taj način možemo govoriti o vrijednostma unutar kurikuluma. U pedagogijskoj se znanosti i školskoj praksi vodimo za činjenicom da u kreiranju (sukonstrukciji), ali i provođenju kurikuluma trebaju sudjelovati svi dionici odgoja i obrazovanja, ali i mnogi drugi organizirani i prikriveni činitelji (Previšić, 2005). Nastavni i školski proces neponovljivi su procesi i teško je sve predvidjeti - planirati i programirati. Stoga, kurikulum stalno 
nadopunjavamo novim sadržajima, aktivnostima i djelovanjima. U tom kontekstu na unaprjeđenje života i rada škole mogu utjecati i učenici od početka obrazovanja.

Tablica 2. Razlike u odgovorima studenata s obzirom na studij Učiteljski studij / studiji na Filozofskom fakultetu

\begin{tabular}{|c|c|c|c|c|}
\hline \multirow[b]{2}{*}{ Ishodi učenja } & \multicolumn{2}{|c|}{ Studij } & \multirow[b]{2}{*}{$\begin{array}{l}F \\
d f\end{array}$} & \multirow[b]{2}{*}{ Sheffè } \\
\hline & $\begin{array}{c}\text { Učiteljski } \\
\text { studij (US) } \\
\text { M } \\
\text { SD } \\
n=55\end{array}$ & $\begin{array}{c}\text { Filozofski } \\
\text { fakultet (FF) } \\
\text { M } \\
\text { SD } \\
\mathrm{n}=54 \\
\end{array}$ & & \\
\hline $\begin{array}{l}\text { Opisuje važnost međusobnog pomaganja. } \\
\text { (znanje) }\end{array}$ & $\begin{array}{l}4.44 \\
0.54\end{array}$ & $\begin{array}{l}4.15 \\
0.86\end{array}$ & $\begin{array}{l}1.078^{*} \\
107\end{array}$ & $U S-F F$ \\
\hline $\begin{array}{l}\text { Objašnjava primjereno postupanje prema } \\
\text { privatnoj imovini i javom dobru. (znanje) }\end{array}$ & $\begin{array}{l}4.00 \\
0.82\end{array}$ & $\begin{array}{l}3.57 \\
0.94\end{array}$ & $\begin{array}{l}3.058^{*} \\
107\end{array}$ & $U S-F F$ \\
\hline $\begin{array}{l}\text { Uključuje se u zajedničke aktivnosti razrednog } \\
\text { odjela i izvršava svoj dio zadatka. (vještina) }\end{array}$ & $\begin{array}{l}4.18 \\
0.82\end{array}$ & $\begin{array}{l}3.74 \\
0.90\end{array}$ & $\begin{array}{l}2.818^{* *} \\
106\end{array}$ & $U S-F F$ \\
\hline $\begin{array}{l}\text { Istražuje i koristi se s više izvora informiranja. } \\
\text { (vještina) }\end{array}$ & $\begin{array}{l}3.36 \\
0.93\end{array}$ & $\begin{array}{l}3.87 \\
0.88\end{array}$ & $\begin{array}{l}0.433^{* *} \\
106\end{array}$ & $F F-U S$ \\
\hline Prepoznaje pojavne oblike korupcije. (vještina) & $\begin{array}{l}3.18 \\
0.86\end{array}$ & $\begin{array}{l}3.61 \\
1.05\end{array}$ & $\begin{array}{l}3.037^{*} \\
107\end{array}$ & $F F-U S$ \\
\hline $\begin{array}{l}\text { Smatra važnim osobni doprinos unaprjeđenju } \\
\text { života i rada škole. (stav) }\end{array}$ & $\begin{array}{l}4.05 \\
0.80\end{array}$ & $\begin{array}{l}3.66 \\
0.94\end{array}$ & $\begin{array}{l}2.493^{*} \\
106\end{array}$ & US - FF \\
\hline
\end{tabular}

${ }^{*} p<.01 ; * p<.001$

Važno je reći da čak i oni studenti koji su manje aktivni (neaktivni) imaju dobre rezultate što se može objasniti činjenicom da su mladi na dobrom putu da budu u još većoj mjeri osvješteni o vrijednostima aktivnosti u društvenoj zajednici (Ljubotina, 2004).

$\mathrm{U}$ ovome dijelu trebalo je provjeriti hipotezu $(\mathrm{H} 2)$ da nema razlika u mišljenjima studenata s obzirom na studij. Pretpostavilo se da, bez obzira na to studiraju li studenti na Filozofskom ili na Učiteljskom fakultetu, dobro procjenjuju dostizanje ishoda učenja s obzirom na znanje, vještine i stavove. Studenti Učiteljskoga fakulteta bolje procjenjuju više ishoda učenja s obzirom na znanje, vještine i stavove (pronađene su razlike u šest ishoda učenja), a studenti Filozofskoga fakulteta bolje procjenjuju dva ishoda učenja s obzirom na vještine. Time je i druga hipoteza djelomično potvrđena.

\section{ZAKLUČAK}

Sudjelovanje djece i mladih u aktivnostima društvene zajednice trebao bi biti prioritet svake zemlje. Škola i različite organizacije u društvenoj zajednici imaju ulogu poticanja aktivnosti kojima će djeca i mladi uočavati socijalnu nepravdu, kršenje ljudskih prava te neučinkovito provođenje vladavine zakona. No prethodno djecu i mlade treba podučiti kako bi na pravilan način razvijali znanja i vještine te oblikovali svoje stavove neovisno od mišljenja drugih i okoline. Građanski odgoj i obrazovanje na sve se sustavniji način provodi u hrvatskom odgoju i obrazovanju. Danas je to područje obavezna međupredmetna tema od 1. razreda osnovne škole do 4. 
razreda srednje škole, a kroz domenu Društvena zajednica djecu i mlade uvodi se u aktivnosti i sudjelovanje u društvenoj zajednici.

Istraživanjem se u radu provjeravaju dvije hipoteze: da studenti koji se smatraju aktivnima bolje procjenjuju dostizanje ishoda učenja s obzirom na znanje, vještine i stavove i da nema razlika u mišljenjima studenata s obzirom na studij. Rezultati pokazuju da su utvrđene razlike s obzirom na znanje i vještine $u$ nekim ishodima učenja, ali nisu u ishodima učenja $s$ obzirom na stavove, već su općenito gledajući ishode učenja s obzirom na stavove studenti visoko procijenili. Studenti Učiteljskoga fakulteta bolje procjenjuju više ishoda učenja s obzirom na znanje, vještine i stavove, a studenti Filozofskoga fakulteta bolje procjenjuju dva ishoda učenja s obzirom na vještine. Razmotrimo li rezultate u njihovoj cijelosti, značaj aktivnosti u društvenoj zajednici prepoznat je i mladi (studenti - budući učitelji/nastavnici) svjesni su njihove važnosti (Ljubotina, 2004).

Rezultati u ovome radu doprinose razvoju mišljenja mladih o značaju aktivnosti u društvenoj zajednici. Studenti u inicijalnom obrazovanju trebaju shvatiti vrijednost tih aktivnosti kako bi mogli kod djece/učenika promicati aktivno zalaganje i sudjelovanje. Ograničenje u ovome istraživanju može predstavljati manji broj studenata u istraživanju, no u usporedbi s drugim istraživanjima pokazuje sliku u odgoju i obrazovanju današnjice u području uključivanja mladih u aktivnosti zajednice.

\section{LITERATURA}

Adler, R. P. i Goggin, J. (2005). What do we mean by "Civic engagement“? Journal of Transformative Education, 3, 236-253. doi:10.1177/ 1541344605276792

Baker, P. M., Bricout, J. C., Moon, N. W., Coughlan, B. i Pater, J. (2013). Communities of participation: A comparison of disability and aging identified groups on Facebook and LinkedIn. Telematics and Informatics, 30(1), 22-34.

Bašić, S. (2007). Promoviranje 'pozitivnog razvoja mladih' u postkonfliktnom okruženju putem osnaživanja i civilnog angažmana u zajednici. Godišnjak Fakulteta političkih nauka, 2, 260-275.

Batarelo, I., Čulig, B., Novak, J., Reškovac, T. i Spajić-Vrkaš, V. (2010). Demokracija i ljudska prava u osnovnim školama: teorija i praksa. Zagreb: Centar za ljudska prava.

Bäckman, E. i Trafford, B. (2007). Demokratsko upravljanje školama. Zagreb: Vijeće Europe.

Buljubašić-Kuzmanović, V. (2012). Škola kao zajednica odrastanja. Pedagogijska istraživanja, 9(1/2), 43-55.

Checkoway, B. (2011). What is youth participation? Children and youth services review, 33(2), 340345.

Ćurko, B. i Kragić, I. (2012). Tko se boji korupcije još? Metodički ogledi, 19(2), 43-58.

Delanty, G. (2000). Citizenship in the Global Age: Culture, Society and Politics. Buckingham: Open University Press.

Delanty, G. (2006). Community. London \& New York: Routledge.

Diković, M. (2013a). Ključne kompetencije učitelja u odgoju i obrazovanju za građanstvo. Život $i$ škola: časopis za teoriju i praksu odgoja i obrazovanja, 59(1), 326-340.

Diković, M. (2013b). Značaj razrednoga ozračja u građanskom odgoju i obrazovanju. Pedagogijska istraživanja, 10(2), 327-339.

Diller, E. C. (2001). Citizens in service: The challenge of delivering civic engagement training to national service programs. Washington, DC: Corporation for National and Community Service.

Domović, V. (2004). Školsko ozračje i učinkovitost škole. Zagreb: Naklada Slap.

Hart, R. A. (2013). Children's participation: The theory and practice of involving young citizens in community development and environmental care. London \& New York: Routledge.

Holgersson, J., Karlsson, F. (2014). Public e-service development: Understanding citizens' conditions for participation. Government Information Quarterly, 31(3), 396-410. 
Hoskins, B. (2006). Working towards Indicators for Active Citizenship. Ispra: European Commission and CRELL (Centre for Research on Lifelong Learning) and Council of Europe.

Ilišin, V. (2003). Mediji u slobodnom vremenu djece i komunikacija o medijskim sadržajima. Medijska istraživanja, 9(2), 9-34.

Kotlar, V., Milanja, I., Jakšić, K. i Bionda, M. (2017). Stavovi o volontiranju i vrednovanju volonterskog rada studenata Sveučilišta u Zadru. Magistra ladertina, 11(1), 105-130.

Ledić, J. i Ćulum, B. (2010). Učenje zalaganjem u zajednici - integracija visokoškolske nastave i zajednice u procesu obrazovanja društveno odgovornih i aktivnih građana. Revija za socijalnu politiku, 17(1), 71-88.

Ljubotina, D. (2004). Mladi i socijalna pravda. Revija za socijalnu politiku, 11(2), 159-175.

Mehmedović, J. (2018). Internetsko nasilje među tinejdžerima. DHS-Društvene i humanističke studije: časopis Filozofskog fakulteta u Tuzli, 3(2), 397-414.

Mesić, M. (2006). Multikulturalizam. Društveni i teorijski izazovi. Zagreb: Školska knjiga.

Miliša, Z., Tolić, M. i Vertovšek, N. (2009). Mediji i mladi. Zagreb: Sveučilišna knjižara.

Nacionalni okvirni kurikulum za predškolski odgoj i obrazovanje te opće obavezno i srednjoškolsko obrazovanje (MZO, 2011). Preuzeto s http://mzos.hr/datoteke/Nacionalni_okvirni_kurikulum. $\mathrm{pdf}_{2}$ 19. 4. 2019.

Odluka o donošenju kurikuluma za međupredmetnu temu Građanski odgoj i obrazovanje za osnovne i srednje škole u Republici Hrvatskoj (NN 10/2019). Preuzeto s https://narodne-novine.nn.hr/ clanci/sluzbeni/2019_01_10_217.html, 17.4.2019.

Prijedlog Nacionalnog kurikuluma međupredmetne teme Građanskog odgoja i obrazovanja (2016). Preuzeto s http://www.kurikulum.hr/wp-content/uploads/2016/03/Građanski-odgoj.pdf, 16.4. 2019.

Program međupredmetnih i interdisciplinarnih sadržaja građanskog odgoja i obrazovanja za osnovne i srednje škole. Preuzeto s https://mzo.hr/sites/default/files/migrated/program_go_os_ss .pdf, 19.4.2019.

Skok, P. (2002). Izvanučionička nastava. Zagreb: Pedagoški servis.

Spajić-Vrkaš, V., Kukoč, M. i Bašić, S. (2001). Obrazovanje za ljudska prava i demokraciju: Interdisciplinarni rječnik. Zagreb: Hrvatska komisija za UNESCO i Projekt „Obrazovanje za mir i ljudska prava za hrvatske osnovne škole“.

Stanojević, D. (2009). Samopercepcija učenika u kontekstu vršnjačkog kooperativnog učenja. Didactica Slovenica-Pedagoška obzorja, 2, 20-43.

Tatković, N., Diković, M. i Štifanić, M. (2015). Odgoj i obrazovanje za razvoj danas i sutra-Ekološke i društvene paradigme. Pula: Sveučilište Jurja Dobrile u Puli.

Tönnies, F. (2002). Community and Society. Mineola, New York: Dover Publications, Inc.

Vrgoč, H. (1997). Školsko i razredno-nastavno ozračje u funkciji unapređivanja odgoja i obrazovanja. U: Vrgoč, H. i Bošnjak, B. (ur.) Školsko i razredno-nastavno ozračje: put prema kvalitetnijoj hrvatskoj školi i nastavi: zbornik stručno-znanstvenog skupa (str. 9-16). Zagreb: Hrvatski pedagoškoknjiževni zbor.

Zeman, M. G. i Zeman, Z. (2010). Uvod u sociologiju (održivih) zajednica. Zagreb: Institut društvenih znanosti Ivo Pilar.

Zloković, J. (2010). Kriza vzgoje - ali potrebujemo socialno in družinsko „razstrupljanje“? Iskanja, 29(39-40), 19-31. 
Marina Diković, Tina Drenjančević AKTIVNOSTI MLADIH U DRUŠTVENOJ ZAJEDNICI - MIŠLENJE.

\title{
Youths' Activities in Community - Students' Opinions (Future Teachers)
}

\begin{abstract}
Young people's participation in community activities is one of the important aspects of the active citizenship. This participation develops within the framework of the Citizen ship education and since 2014 was implemented in the Croatian educational system as a mandatory area. The goal, among other goals, is to adopt competences for inclusion in the community activities. The aim of the research in this paper was to examine students' opinions (future teachers) about student achievement of learning outcomes with regard to knowledge, skills and attitudes based on Curriculum of Citizenship Education for Primary and Secondary Schools in the Republic of Croatia (10/2019). The research was conducted on a sample of 109 students from Juraj Dobrila University of Pula. For this research, students are divided into two groups, those who have been self-evaluated as active and those who are considered inactive in the community. There are more differences in the students' view of achieving learning outcomes with regard to knowledge, then learning outcomes with regard to skills, but there are no differences in the opinion of achieving learning outcomes with regard to attitudes. Students from the Faculty of Educational Sciences better evaluate learning outcomes with regard to knowledge, skills and attitudes. In order to form attitudes, as an important segment of civic competence, it is necessary that children and young people practice active citizenship.
\end{abstract}

Keywords: citizenship education; learning outcomes; students' opinion; community; knowledge, skills and attitudes

\section{Aktivitäten der Jugendlichen im Gemeinwesen - Meinung der Studierenden (angehenden LehrerInnen)}

Zusammenfassung: Die Teilnahme der Jugendlichen an gesellschaftlichen Aktivitäten ist ein wichtiger Aspekte des aktiven Bürgertums. Entfaltet wird sie durch die Bürgerliche Erziehung, die im kroatischen Bildungs- und Erziehungssystem seit 2014 als obligatorisch durchgeführt wird mit dem Ziel, u.a. die Kompetenzen für die Teilnahme an den gesellschaftlichen Aktivitäten zu erwerben. Das Ziel dieser Forschung ist, die Meinungen der Studierenden (angehenden LehrerInnen) über die Errungenschaft der Ergebnisse der Lehre im Bezug auf das Wissen, Fertigkeiten und Stellungnahmen auf Grund des Curriculums der bürgerlichen Erziehung in Grund- und Gesamtschulen in der Republik Kroatien (10/2019) zu befragen. An der Studie haben sich 109 Studierende der Juraj Dobrila Universität Pula beteiligt. Für Forschungszwecke wurden die Studierenden in zwei Gruppen geteilt: einerseits diejenigen, die sich als aktiv im Gemeinwesen einschätzen, andererseits diejenigen, die sich selber eher als inaktiv bewerten. In Bezug auf das Wissen und die Fertigkeiten lassen sich mehrere Unterschiede in den Meinungen der Studierenden über die Errungenschaft der Ergebnisse der Lehre feststellen, aber es gibt keine Unterschiede in den Meinungen über die Errungenschaft der Ergebnisse der Lehre bezüglich der Stellungnahmen. Studierende des Lehramtsstudiums können die Ergebnisse der Lehre in Bezug auf das Wissen, die Fertigkeiten und die Stellungnahmen besser einschätzen. Es ist notwendig, dass Kinder und Jugendliche das aktive Bürgertum praktizieren, um Stellungen nehmen zu können, was ein wichtiges Segment der bürgerlichen Kompetenz ist.

Schlüsselwörter: bürgerliche Erziehung; Ergebnisse der Lehre; Meinungen der Studierenden; Gemeinschaft; Wissen, Fertigkeiten und Stellungnahmen 